INFLAMMATORY BOWEL DISEASE

\title{
Influence of IL-6, COLIAI, and VDR gene polymorphisms on bone mineral density in Crohn's disease
}

\author{
C E Todhunter, A Sutherland-Craggs, S A Bartram, P T Donaldson, A K Daly, \\ R M Francis, J C Mansfield, N P Thompson
}

See end of article for authors' affiliations

Correspondence to: Dr N P Thompson, Department of Medicine, Freeman Hospital, High Heaton, Newcastle Upon Tyne, NE7 7DN, UK; nick.thompson@ nuth.nhs.uk

Revised version received 17 June 2005 Accepted for publication 21 June 2005 Published online first 11 July 2005

Background: Osteoporosis is an important cause of morbidity in patients with Crohn's disease. The pathogenesis of reduced bone mineral density (BMD) is multifactorial. A range of genetic factors have been implicated in other populations of patients with osteoporosis.

Aim: To investigate the influence of interleukin 6 (IL-6), collagen type $1 \alpha 1$ (COLlAl), and vitamin D receptor gene (VDR) single nucleotide polymorphisms (SNP) on BMD in patients with Crohn's disease.

Patients: A cohort of 245 well characterised patients with Crohn's disease were recruited from the inflammatory bowel disease register at the Freeman Hospital and Royal Victoria Infirmary, Newcastle upon Tyne, and the Queen Elizabeth Hospital, Gateshead, UK.

Methods: Patients were genotyped for IL-6 C-174G SNP, COL1A1 Spl binding site G T SNP, VDR Taql, and Fok1 SNPs, and CARD15 R702W, G908R, and L1007fs SNPs. BMD was measured at the lumbar spine (LSP) and hip using dual energy $x$ ray absorptiometry.

Results: A total of 158 female and 87 male patients, aged 24-70 years (mean 44), were recruited. There were no significant differences in the distribution of the tested SNPs when analysed for age, body mass index, pre/post-menopausal status, smoking, or steroid use. Two hundred and thirteen patients were genotyped for the IL-6 SNP. LSP and total hip BMD was significantly lower in patients with the GG genotype $(48 \%)$ than the CC genotype (15\%) $(p=0.041, p=0.014)$. One hundred and eighty patients were genotyped for the COLIA1 SNP. There was no significant difference in BMD at LSP. Hip BMD was significantly lower in heterozygous patients compared with homozygous wild-types $(p=0.034)$. There were no significant differences in BMD between genotypes for the two VDR SNPs or the CARD15 genotypes examined.

Conclusion: IL-6 and COLIAl gene polymorphisms influence BMD in patients with Crohn's disease but the particular VDR gene polymorphisms studied do not have a major effect.

O steoporosis is an important cause of morbidity in patients with Crohn's disease, with a fracture prevalence of up to $22 \%$ in those who are osteoporotic ${ }^{1}$ and an overall increase in low energy fracture rate compared with the general population. ${ }^{23}$ As the majority of osteoporotic fractures are asymptomatic at the time of fracture, ${ }^{1}$ low bone mineral density (BMD) provides a useful marker for risk of later symptomatic fracture. ${ }^{45}$ Low BMD is more common in patients with Crohn's disease than those with ulcerative colitis. ${ }^{6}$ The pathogenesis of the reduced BMD found in those with Crohn's disease is multifactorial. Various risk factors have been identified for reduced BMD, including corticosteroid use, ${ }^{7}$ low body mass index (BMI), ${ }^{7-9}$ disease duration, ${ }^{10}$ age, ${ }^{11}$ and smoking. ${ }^{12}$ In addition, several genes have been implicated in the pathogenesis of osteoporosis in other at risk populations. Twin studies indicate that $60-80 \%$ of BMD may be genetically determined. ${ }^{13}$

Finding a genotype that is a marker for those at risk of lower BMD could enable targeted therapy before osteoporosis develops. Twin studies have linked polymorphisms of the vitamin D receptor $(V D R)$ gene and BMD in healthy women ${ }^{14}$ although these findings have not always been reproducible. ${ }^{15}$ A meta-analysis of 16 studies suggest a weak effect for VDR polymorphisms. ${ }^{16}$ VDR is an important regulator of calcium metabolism and bone cell function. In addition, $V D R$ polymorphisms have been found to influence calcium absorption from the intestine. ${ }^{17} V D R$ polymorphisms have also been implicated in susceptibility to Crohn's disease ${ }^{18}$ and therefore in a case control manner we investigated this association.

The proinflammatory cytokine interleukin 6 (IL-6) has also been implicated in the pathogenesis of osteoporosis. IL-6 influences osteoclast function and stimulates bone resorption. ${ }^{19}$ Studies have found a link between polymorphisms in the $I L-6$ gene and BMD in otherwise healthy women ${ }^{20}$ and in those with inflammatory bowel disease. ${ }^{21}$

Collagen type $1 \alpha \mathrm{l}(\mathrm{COL1Al})$ gene mutations are responsible for the condition osteogenesis imperfecta. ${ }^{22}$ Less dramatically, polymorphisms in this gene have been found to influence BMD in previous studies in a healthy population. ${ }^{23}{ }^{24}$ Polymorphisms in the COL1Al gene have been found to alter bone strength by altering binding affinity for the transcription factor Spl. ${ }^{25}$ To date, there are no published studies of the effect of COL1Al single nucleotide polymorphism (SNPs) on BMD in inflammatory bowel disease.

We therefore wished to investigate the potential relationship between well recognised apparently functional SNPs of VDR, IL-6, and COLIAI and BMD in a cohort of well characterised patients with Crohn's disease.

Abbreviations: IL-6, interleukin 6; COLIAI, collagen type $1 \alpha 1$; VDR, vitamin $\mathrm{D}$ receptor; $\mathrm{SNP}$, single nucleotide polymorphism; $\mathrm{BMD}$, bone mineral density; LSP, lumbar spine; BMI, body mass index; PCR, polymerase chain reaction 
The SNPs investigated were: the Fokl and Taql polymorphisms of $V D R$, the G to C SNP at position -174 of $I L-6$, and a polymorphism at the $\mathrm{Spl}$ transcription factor binding site of COLIAI.

Polymorphisms in the CARD15 gene on chromosome 16 have been identified as susceptibility markers for Crohn's disease $^{26}$ and are known to be associated with ileal disease rather than purely colonic disease. ${ }^{27}$ Osteoporosis is a complication of severe Crohn's disease; we investigated whether CARD15 mutations are associated with BMD.

\section{PATIENTS AND METHODS}

Patients were recruited from the inflammatory bowel disease register at the Freeman Hospital and the Royal Victoria Infirmary, Newcastle upon Tyne, and the Queen Elizabeth Hospital, Gateshead, UK. All patients had a diagnosis of Crohn's disease and were under the care of either surgical or medical gastroenterologists and were diagnosed by a combination of radiology, endoscopy, and biopsy. Only patients aged 24-70 years were included, and women who were pregnant or planning a pregnancy were excluded because of the potential risk from exposure to ionising radiation during bone densitometry. Initial demographic data were collected by questionnaire, including age, smoking history, and reproductive and menstrual history in women. Details including duration and site of disease, corticosteroid use in months, and surgical and drug history were obtained both through direct interview and from the medical notes. Prior to bone densitometry, height and weight were measured and BMI calculated. All patients gave informed consent to participate. The Newcastle upon Tyne joint ethics committee granted ethics approval.

For comparison, when testing the hypothesis that the VDR genotype is associated with Crohn's disease, a geographically and racially matched cohort of healthy controls was recruited from in vitro fertilisation donors and healthcare workers.

\section{BMD measurement}

BMD was measured at the lumbar spine (LSP) and total left hip using dual energy $x$ ray absorptiometry (QAR 2000; Hologic Inc., Waltham, Massachusetts, USA), as previously described. ${ }^{28}$ Osteoporosis is defined by the WHO as a bone density of 2.5 or more standard deviations below the mean value for young adults, and osteopenia as a $\mathrm{T}$ score of -1 to -2.5 at any site. ${ }^{29}$ Classification as normal BMD, osteopenic, or osteoporotic is dependent on the site with the lowest BMD $\mathrm{T}$ score.

\section{Genotyping Determination of VDR Taql genotype}

A $340 \mathrm{bp}$ fragment, which included the site of the $\mathrm{T}$ to $\mathrm{C}$ polymorphism at codon 352 in exon 9 of the VDR gene on chromosome 12, was amplified in a $25 \mu \mathrm{l}$ reaction mixture containing $200 \mu \mathrm{M}$ each of dATP, dCTP, dGTP, and dTTP (ABgene, Surrey, UK), $10 \mathrm{mM}$ Tris- $\mathrm{HCl}, \mathrm{pH} 8.3,50 \mathrm{mM} \mathrm{KCl}$, $0.01 \%$ gelatin, $1 \mathrm{U}$ Taq Polymerase (ABgene), $0.5 \mu \mathrm{M}$ of each primer, and $1 \mu \mathrm{l}$ (approximately $0.2-0.5 \mu \mathrm{g}$ ) of template DNA on a Perkin-Elmer GeneAmp 9700. The alleles relating to this polymorphism are designated " $\mathrm{t}$ " (Taq I site present) or $\mathrm{T}$ (Taq I site absent).

The primers used were: 5' CAg AgC ATg gAC Agg gAg CAA g-3' forward and 5' ggg TgT ACg TCT gCA gTg Tg-3'reverse (Oswel, Southampton, UK).

The polymerase chain reaction (PCR) amplification conditions were as follows: initial denaturation at $94^{\circ} \mathrm{C}$ for six minutes followed by 35 cycles of, $94^{\circ} \mathrm{C}$ for 45 seconds, $63^{\circ} \mathrm{C}$ for 60 seconds, followed by $72^{\circ} \mathrm{C}$ for 75 seconds, and a final extension at $72^{\circ} \mathrm{C}$ for seven minutes.
Following amplification, $15 \mu \mathrm{l}$ of the product were digested with 2.5 units of Taq I (ABgene) at $65^{\circ} \mathrm{C}$. Digested restriction fragments were separated on $2.5 \%(\mathrm{w} / \mathrm{v})$ agarose (Sigma, Poole, Dorset, UK) gels, with $1 \times$ Tris-Borate-EDTA (TBE) running buffer (Sigma) Samples of known genotype were run as controls and a water negative (DNA free) control in each batch.

Bands were visualised on an Alpha Innotech Imager system and assigned as follows: T/T $340 \mathrm{bp}$ only; T/t $340 \mathrm{bp}$, $293 \mathrm{bp}$, and $47 \mathrm{bp} ; \mathrm{t} / \mathrm{t} 293 \mathrm{bp}$ and $47 \mathrm{bp}$.

\section{Determination of VDR Fok 1 genotype}

A $265 \mathrm{bp}$ fragment, which includes the site of a $\mathrm{C}$ to $\mathrm{T}$ polymorphism at the start codon, was amplified as above. The alleles which result from this change are designated "f" (FokI site present) or "F" (FokI site absent).

The primers used were: 5' ACg Tgg CCC Tgg CAC TgA CTC TgC TCT-3' forward and 5' ATg gAA ACA CCT TgC TTC TTC TCC CTC-3' reverse (Oswel).

The PCR amplification conditions were as follows: initial denaturation at $94^{\circ} \mathrm{C}$ for five minutes followed by 32 cycles of $94^{\circ} \mathrm{C}$ for 45 seconds, $58^{\circ} \mathrm{C}$ for 45 seconds, followed by $72^{\circ} \mathrm{C}$ for 45 seconds, and a final extension at $72^{\circ} \mathrm{C}$ for seven minutes.

Following amplification, $15 \mu \mathrm{l}$ of the product were digested with 4 units of FokI restriction endonuclease (ABgene) at $37^{\circ} \mathrm{C}$. Digested restriction fragments were separated on $2 \%$ $(\mathrm{w} / \mathrm{v})$ agarose (Sigma) gels as described above. Genotypes were assigned as follows: F/F 265 bp only; F/f 265 bp, 169 bp, and $96 \mathrm{bp} ; \mathrm{f} / \mathrm{f}, 169 \mathrm{bp}$ and $96 \mathrm{bp}$.

\section{Determination of IL- $6-174$ genotype}

A 431 bp fragment, which includes the site of a $G$ to $C$ polymorphism at position -174 in the promoter region of the IL-6 gene, was amplified as above. On digestion with NlaIII, the wild-type sequence with $G$ at position -174 is not digested whereas a $\mathrm{C}$ at -174 creates a restriction site for NIaIII and is digested. The primers used were: 5' CAg AAg AAC TCA gAT gAC Tgg-3' forward and 5' gTg ggg CTg ATT ggA AAC C-3' reverse (Oswel).

The PCR reaction conditions for amplification were as follows: initial denaturation at $95^{\circ} \mathrm{C}$ for five minutes followed by five cycles of $95^{\circ} \mathrm{C}$ for 30 seconds, $58^{\circ} \mathrm{C}$ for 60 seconds, followed by $72^{\circ} \mathrm{C}$ for 60 seconds, followed by 25 cycles of $95^{\circ} \mathrm{C}$ for 30 seconds, $56^{\circ} \mathrm{C}$ for 60 seconds, followed by $72^{\circ} \mathrm{C}$ for 60 seconds, followed by five cycles of $95^{\circ} \mathrm{C}$ for 30 seconds, $54^{\circ} \mathrm{C}$ for 60 seconds, followed by $72^{\circ} \mathrm{C}$ for 60 seconds and a final extension at $72^{\circ} \mathrm{C}$ for seven minutes.

Following amplification, $15 \mu \mathrm{l}$ of the product were digested with 2.5 units of NlaIII restriction endonuclease (ABgene) at $37^{\circ} \mathrm{C}$. Digested restriction fragments were separated on $2 \%$ $(\mathrm{w} / \mathrm{v})$ agarose gels, as described above. For the various genotypes, the following band patterns were obtained: $G / G$ $229 \mathrm{bp}, 173 \mathrm{bp}$, and $29 \mathrm{bp}$; G/C $229 \mathrm{bp}, 173 \mathrm{bp}$, and $122 \mathrm{bp}$; C/C 229 bp, 122 bp, 51 bp, and 29 bp.

\section{Determination of COLIA 1 genotype}

A $280 \mathrm{bp}$ fragment, which included the site of the G T polymorphism at the Spl binding site in the first intron of COLIAl gene, was amplified as above. The primers used were: 5' CTG GAC TAT TTG CGG ACT TTT TGG-3' forward and 5' GTC CAG CCC TCA TCC TGG CC-3' reverse (Oswel).

The PCR reaction conditions for amplification were as follows: initial denaturation at $94^{\circ} \mathrm{C}$ for five minutes followed by 30 cycles of $94^{\circ} \mathrm{C}$ for one minute, $64^{\circ} \mathrm{C}$ for one minute, and $72^{\circ} \mathrm{C}$ for one minute.

Following amplification, $10 \mu \mathrm{l}$ of the product were digested with 1 unit of $M s c l$ restriction endonuclease (New England Biolabs) at $37^{\circ} \mathrm{C}$. Digested restriction fragments were separated by polyacrylamide gel electrophoresis on $10 \%$ 


\begin{tabular}{|ll|}
\hline \multicolumn{2}{l|}{ Table $1 \quad$ Patient demographics } \\
\hline Characteristic & $\mathbf{n = 2 4 5}$ \\
\hline Female & 158 \\
Age (y) & $44.4(11.4)(24-70)^{*}$ \\
Post menopausal & 62 \\
Smoking & 92 \\
Never smoked & 75 \\
Ex smoker & 78 \\
Current smoker & 28 \\
Steroid use & 144 \\
Never & 73 \\
Previous use & $45(66.4)(0-372)^{*}$ \\
Current steroids & $14.3(9.5)(0.5-50)^{*}$ \\
Duration of steroids (months) & \\
Duration of disease (y) & \\
\hline *Values are mean (SD) (range). & \\
\hline
\end{tabular}

polyacrylamide gels, with $1 \times$ TBE running buffer (Sigma). Samples of known genotype were run as controls, and water as a negative (DNA free) control in each batch.

Following electrophoresis for four hours at $160 \mathrm{mV}$, bands were visualised on an Alpha Innotech Imager system. The patterns corresponding to the various genotypes were as follows: homozygous wild-type (GG) $280 \mathrm{bp}$ only; heterozygous (GT) 280 and $260 \mathrm{bp}$; and homozygous mutant (TT) 260 bp only.

\section{CARD 15 genotyping}

This was performed as previously reported in Cuthbert and colleagues $^{27}$ in Professor C Mathew's laboratory, Department of Medical and Molecular Genetics, Guy's, Kings and St Thomas' School of Medicine, London, UK. In brief, genotypes of the polymorphisms R702W, G908R, and 3020insC were determined using the TaqMan biallelic discrimination system. Primers for exon amplification were designed on the basis of the Genbank sequence NT_019610.

\section{Statistical analysis}

To look for differences in BMD at the hip and LSP between genotypes, ANOVA was employed. Where this was significant, Tukey's test for multiple comparisons was used to compare differences between groups. Multiple regression analysis was used to determine additional risk of steroid use and genotype.

\section{RESULTS}

\section{Baseline characteristics}

A total of 245 patients with Crohn's disease were studied (table 1): 54 (22\%) were osteoporotic at any site, 106 (43\%) were osteopenic at any site, and 160 (65\%) had normal bone density. There were no significant differences between any genotypes and age, BMI, pre/post menopausal, smoking, or steroid use (data not shown). All controls were residents of the North Tyneside-Newcastle region of North East England

\begin{tabular}{|c|c|c|c|}
\hline VDR Taq 1 genotype & CC & TC & $\pi$ \\
\hline$(n=244)$ & $37(15 \%)$ & 130 (53\%) & $76(31 \%)$ \\
\hline VDR Fokl genotype & FF & & \\
\hline$(n=240)$ & 85 (35\%) & $121(50 \%)$ & 33 (14\%) \\
\hline $\begin{array}{l}\text { IL-6 genotype } \\
(n=213)\end{array}$ & $\begin{array}{l}\mathrm{CC} \\
32(15 \%)\end{array}$ & $\begin{array}{l}\text { GC } \\
76(36 \%)\end{array}$ & $\begin{array}{l}\text { GG } \\
104(49 \%)\end{array}$ \\
\hline COLlAl genotype & GG & GT & $\pi$ \\
\hline$(n=180)$ & 95 (53\%) & $49(27 \%)$ & $36(20 \%)$ \\
\hline $\begin{array}{l}\text { CARD 15 genotype } \\
(\mathrm{n}=223)\end{array}$ & $\begin{array}{l}\text { Wild-type } \\
167 \text { (75\%) }\end{array}$ & $\begin{array}{l}\text { Heterozygote } \\
46(21 \%)\end{array}$ & $\begin{array}{l}\text { Homozygote* } \\
10(4 \%)\end{array}$ \\
\hline
\end{tabular}

and all were of Northern European Caucasoid ancestry. None had a history of autoimmune disease or inflammatory bowel disease.

\section{Genotype}

All genotypes were in Hardy-Weinberg equilibrium. Genotype distributions are shown in table 2. Comparing genotype distribution of COL1A1, IL-6, and VDR Fokl with those of 257 healthy controls, there were no statistically significant differences. There was no difference in VDR Taql genotype frequency between patients with Crohn's disease and controls $(p=0.10)$. Control genotype frequency was CC 40 (15\%), TC $115(45 \%)$, and TT $102(40 \%)$.

\section{Genotype and bone mineral density VDR Taq 1}

There was no significant difference in BMD at the LSP or hip between VDR Taql genotypes. There was also no difference in T score at the LSP and hip and VDR Taql genotype (table 3).

\section{VDR Fok 1}

There was no significant difference in BMD at the LSP or hip between VDR Fokl genotypes. There was also no difference in $\mathrm{T}$ score at the LSP and hip and VDR Fokl genotype (table 3).

\section{IL-6}

At the LSP there was a significant difference in BMD between $I L-6$ genotypes $(\mathrm{p}=0.041)$. This difference was between the GG and CC genotypes by pairwise comparison allowing for multiple testing. The CC genotype had a higher mean BMD $\left(1.03 \mathrm{~g} / \mathrm{cm}^{2}\right)$ than the GG genotype $\left(0.95 \mathrm{~g} / \mathrm{cm}^{2}\right) \quad(95 \%$ confidence interval for the difference (CI) 0.0032-0.1524). There was only a trend towards significance between $\mathrm{T}$ score and genotype $(\mathrm{p}=0.065)$ (table 3$)$.

At the hip there was a significant difference in BMD between $I L-6$ genotypes $(p=0.014)$ (table 3 , fig 1$)$. The CC genotype had a higher mean BMD of $0.93 \mathrm{~g} / \mathrm{cm}^{2}$ compared with the GG genotype (mean BMD $0.48 \mathrm{~g} / \mathrm{cm}^{2} ; 95 \%$ CI 0.0186-0.159). The difference between genotype groups when BMD was expressed as $\mathrm{T}$ score was statistically significant $(\mathrm{p}=0.013)$. Mean $\mathrm{T}$ score was -0.709 for CC genotype and -1.37 for GG genotype (95\% CI $0.119-1.208$ ).

\section{COLIA1}

There was no significant difference in LSP BMD between COL1Al genotypes $(\mathrm{p}=0.144)$. There was also no significant difference in T score at the LSP between genotypes $(\mathrm{p}=0.14$ and $\mathrm{p}=0.24)$ (table 3$)$.

At the hip there was a significant difference in BMD between COL1Al genotypes $(\mathrm{p}=0.034)$ (table 3, fig 2 ). This was between the homozygous wild-type (GG) and heterozygous (GT) genotypes. Mean BMD for the GG genotype was $0.88 \mathrm{~g} / \mathrm{cm}^{2}$ and for GT $0.81 \mathrm{~g} / \mathrm{cm}^{2}$ (95\% CI 0.0051-0.1307). There was also a significant difference in $\mathrm{T}$ scores between genotypes $(p=0.025)$. Again, the GG genotype had a higher T score $(-1.03)$ than the GT genotype $(-1.59$; $95 \%$ CI $0.066-$ $1.063)$.

\section{Genotype steroid interaction}

Using adjusted $r^{2}$, the variation in BMD at the hip due to duration of steroid use was 5.1\%. An additional nonsignificant variation due to genotype was $1.2 \%(p=0.09)$. However, there was a significant additional reduction in BMD at the hip with $I L-6$ GG genotype compared with CC of $5.3 \%$ (95\% CI $10.4-0.2 \% ; p=0.04)$. There was no significant effect of GC genotype compared with CC genotype.

There was also a significant reduction in BMD at the hip with COLIAI GT genotype compared with GG of 5.8\% (95\% 
Table 3 Bone mineral density (BMD) for each genotype

\begin{tabular}{|c|c|c|c|c|}
\hline Genotype & $\begin{array}{l}\text { LSP BMD } \\
\left(\mathrm{g} / \mathrm{cm}^{2}\right)\end{array}$ & LSP T score & $\begin{array}{l}\text { Total hip } \\
\text { BMD }\left(\mathrm{g} / \mathrm{cm}^{2}\right)\end{array}$ & Hip T score \\
\hline \multicolumn{5}{|l|}{ VDR Taql } \\
\hline $\mathrm{CC}$ & $0.98(0.13)$ & $-0.73(1.19)$ & $0.86(0.15)$ & $-1.15(1.20)$ \\
\hline TC & $0.98(0.16)$ & $-0.70(1.47)$ & $0.87(0.15)$ & $-1.12(1.25)$ \\
\hline$\pi$ & $0.96(0.15)$ & $-0.95(1.44)$ & $0.84(0.15)$ & $-1.29(1.17)$ \\
\hline \multicolumn{5}{|l|}{ VDR Fokl } \\
\hline ff & $0.95(0.18)$ & $-1.04(1.67)$ & $0.85(0.19)$ & $-1.30(1.54)$ \\
\hline $\mathrm{Ff}$ & $0.97(0.15)$ & $-0.80(1.41)$ & $0.85(0.14)$ & $-1.21(1.15)$ \\
\hline FF & $0.99(0.15)$ & $-0.65(1.35)$ & $0.89(0.15)$ & $-1.05(1.16)$ \\
\hline \multicolumn{5}{|l|}{ IL-6 } \\
\hline $\mathrm{CC}$ & $1.03(0.15)^{\star}$ & $-0.33(1.41)$ & $0.93(0.14)^{*}$ & $-0.71(1.03)^{*}$ \\
\hline GC & $0.99(0.17)$ & $-0.69(1.50)$ & $0.87(0.14)$ & $-1.06(1.09)$ \\
\hline GG & $0.95(0.15)$ & $-0.98(1.37)$ & $0.48(0.15)$ & $-1.37(1.25)$ \\
\hline \multicolumn{5}{|l|}{ COLIAl } \\
\hline GG & $0.98(0.14)$ & $-0.75(1.33)$ & $0.88(0.15)$ & $-1.03(1.19)$ \\
\hline GT & $0.94(0.15)$ & $-1.15(1.39)$ & $0.81(0.14)^{*}$ & $-1.59(1.18)^{*}$ \\
\hline$\pi$ & $0.99(0.16)$ & $-0.59(1.51)$ & $0.87(0.15)$ & $-1.08(1.27)$ \\
\hline \multicolumn{5}{|l|}{ CARD 15} \\
\hline Wild-type & $0.98(0.15)$ & $-0.77(0.15)$ & $0.87(0.15)$ & $-1.14(1.22)$ \\
\hline Heterozygote & $0.96(0.17)$ & $-0.89(1.50)$ & $0.85(0.15)$ & $-1.26(1.14)$ \\
\hline Homozygote & $0.97(0.16)$ & $-0.95(1.44)$ & $0.88(0.17)$ & $-1.27(1.23)$ \\
\hline
\end{tabular}

CI $11.2-0.4 \% ; \mathrm{p}=0.035$ ) There was no significant effect of TT genotype compared with GG genotype.

There was no significant additional change in LSP BMD with $I L-6$ of COLIAI genotypes.

\section{CARD 15}

There was no significance in BMD or T score between CARD15 genotypes (table 2 ). The frequencies of CARD15 genotypes are shown in table 2. As expected, there was a higher frequency of CARD 15 mutations in the Crohn's disease population than the control group $(\mathrm{n}=104)$ : wild-type $77(91 \%)$, heterozygote $7(7 \%)$, and homozygote 0 .

\section{DISCUSSION}

This was a large study of the relationship between genes and BMD in a well characterised population of patients with Crohn's disease. When analysed by genotype there was no

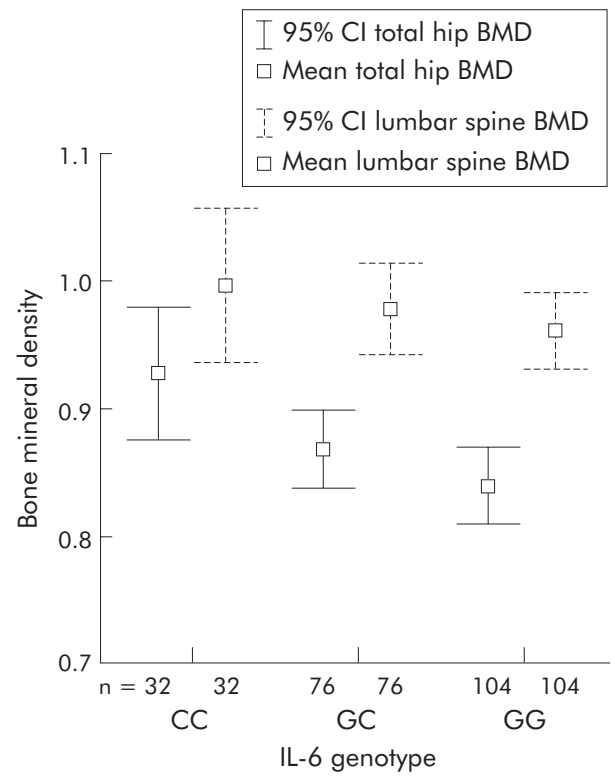

Figure 1 Mean bone mineral density (BMD) in the different interleukin 6 (IL-6) genotype groups. 95\% Cl, 95\% confidence interval. difference in duration of disease, steroid use, age, BMI, or smoking status, allowing valid comparisons between genotypes to be made.

A significant association was found between IL-6 polymorphisms and lower BMD at the LSP and hip in patients with Crohn's disease. The largest difference was seen at the hip where the GG (49\%) genotype had a 9.6\% lower mean BMD than the CC (15\%) genotype; at the LSP there was a $7.5 \%$ difference. From the analysis, the $\mathrm{C}$ allele appears to produce a protective effect as the GC heterozygote had a significantly higher BMD than the GG homozygote.

The finding of an association between $I L-6$ polymorphisms and BMD in Crohn's is consistent with previous work. ${ }^{21}$ Schulte and colleagues ${ }^{21}$ studied 83 patients with a mixture of Crohn's disease and ulcerative colitis. IL-6 polymorphisms have also been associated with lower BMD in post-menopausal

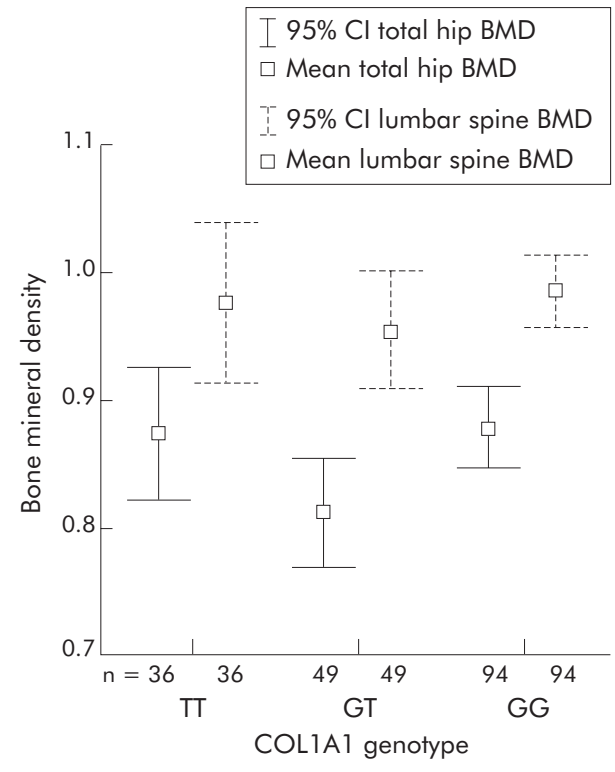

Figure 2 Mean total hip bone mineral density (BMD) in the different collagen type $1 \alpha 1$ (COL1A1) genotype groups. $95 \% \mathrm{Cl}$, 95\% confidence interval. 
women $^{30}$ and with lower peak bone mass in healthy males. ${ }^{31}$ However, in another study of 75 patients with Crohn's disease from a cohort of 105 patients with inflammatory bowel disease, no association was found between $I L-6$ polymorphism and BMD. $^{32}$ This last study however was smaller than the present investigation and BMD was expressed as Z score only, rather than as absolute BMD. In addition, the effect of $I L-6$ seen in the present investigation was relatively small and the earlier study was significantly underpowered by comparison.

$I L-6$ is thought to be involved in bone remodelling and hence development of osteoporosis through stimulation of osteoclast development and regulation of bone resorption. ${ }^{1933} 34$ Higher levels of $I L-6$ have been found in patients with Crohn's disease ${ }^{10}$ and serum levels of $I L-6$ have been found to predict bone loss in post-menopausal women. ${ }^{35}$ Studies in vitro have shown that the CC $I L-6$ genotype results in lower stimulated $I L-6$ promoter activity and in vivo with lower levels of plasma $I L-6 .{ }^{36}$ In post-menopausal women, the CC IL-6 polymorphism was found to be associated with lower bone resorption and less of a loss in BMD compared with the GG genotype. ${ }^{30}$ It is possible that in Crohn's disease, a chronic inflammatory condition that results in higher serum levels of $I L-6$, the CC genotype is protective against $I L-6$ mediated bone resorption.

This study found a significantly lower BMD at the hip in Crohn's disease patients with the heterozygous COLIAl (27\%) genotype compared with the homozygous wild-type $(53 \%)$. At the hip, the heterozygous genotype resulted in a $6 \%$ reduction in BMD. At the hip there was also a significant reduction in $\mathrm{T}$ score to a level below that where therapy is recommended in glucocorticoid induced osteoporosis. ${ }^{37}$

This study is in agreement with other published work on COLIAl gene polymorphisms. COL1Al gene polymorphisms have been associated with low BMD and fractures in other populations. ${ }^{23} 24$ A recent meta-analysis involving 6800 subjects also found a significantly lower BMD at the lumbar spine in the heterozygous group compared with the homozygous wild-type but no significant difference in the homozygous TT group. ${ }^{38}$

COLIAl gene polymorphisms at the Spl binding site are thought to be functional, altering the level of transcription and production of collagen and therefore the physical properties of bone. ${ }^{25}$ Osteoblasts derived from heterozygote subjects were found to have altered production of the collagen $\alpha 1(1)$ chain relative to the $\alpha 2(1)$ compared with wild-type individuals. The same study found that bone strength was reduced in heterozygotes compared with wildtype subjects.

In this analysis there was no association between BMD and either two of the VDR SNPs studied. A meta-analysis of 16 studies in 1996 found a small effect for VDR polymorphisms, ${ }^{16}$ with a $2.4 \%$ difference in BMD between genotypes. Such a small effect has limited clinical significance. The numbers in this study were adequate to detect a difference of $4-5 \%$ between genotypes.

A significant additional effect was found between duration of steroid use and IL-6 GG genotype as well as COLIAI heterozygotes. This effect however was small. It would be useful to be able to comment on the interaction of the different genotypes but this study did not have sufficient numbers to allow that comparison to be made. Further research is needed to investigate whether there is a different response to the treatment of osteoporosis between genotypes.

No association was found in this study between VDR Taql polymorphism and susceptibility to Crohn's disease. This is in contrast with previous published data of 245 patients with Crohn's who were found to have an increased frequency of the tt genotype (synonymous with CC in this study). ${ }^{18}$ The results here are in agreement with a small study of 95 patients with Crohn's disease in which no association was found. ${ }^{39}$

Multiple risk factors for development of osteoporosis have been identified, including BMI and steroid use. ${ }^{7}$ Many studies have found an increased risk of fracture in patients with Crohn's disease ${ }^{124041}$ although this is not consistent. ${ }^{4243}$ Development of risk stratification by genotype as well as clinical risk may enable targeted treatment with agents such as pamidronate ${ }^{28}$ or other bisphosphonates ${ }^{44}$ or calcium supplements, ${ }^{45}$ dependant on risk. Patients could be tested prior to starting corticosteroids for example and those at greater risk of developing osteoporosis be targeted with more aggressive screening and treatment. Crohn's disease patients are younger than other disease groups previously studied and therefore earlier identification of those at risk has potential to be therapeutically important.

\section{ACKNOWLEDGEMENTS}

We would like to thank the National Association for Colitis and Crohn's Disease and the Special Trustees of the Newcastle upon Tyne Hospitals NHS trust for their support. We thank Professor CG Mathew and his team at Complex Disease Genetics Group, Department of Medical and Molecular Genetics, Guy's, King's and St. Thomas' School of Medicine. We would also like to thank the patients for participating.

CE Todhunter was funded by the National Association of Colitis and Crohn's disease.

\section{Authors' affiliations}

C E Todhunter, S A Bartram, N P Thompson, Department of Medicine, Newcastle upon Tyne Hospitals NHS Trust, University of Newcastle upon Tyne, UK

A Sutherland-Craggs, P T Donaldson, School of Clinical Medical Sciences, University of Newcastle upon Tyne, UK

A K Daly, School of Clinical and Laboratory Sciences, University of Newcastle upon Tyne, UK

R M Francis, School of Clinical Medical Sciences, University of Newcastle upon Tyne, UK, and Musculoskeletal Unit, Newcastle upon Tyne Hospitals NHS Trust, University of Newcastle upon Tyne, UK J C Mansfield, Department of Medicine, Newcastle upon Tyne Hospitals NHS Trust, University of Newcastle upon Tyne, UK, and School of Clinical Medical Sciences, University of Newcastle upon Tyne, UK

Conflict of interest: None declared.

\section{REFERENCES}

1 Klaus J, Armbrect G, Steinkamp M, et al. High prevalence of osteoporotic vertebral fractures in patients with Crohn's disease. Gut 2002;51:654-8.

2 Vestergaard P, Krogh K, Rejnmark L, et al. Fracture risk is increased in Crohn's disease, but not in ulcerative colitis. Gut 2000;46:176-81.

3 van Staa TP, Cooper C, Brusse LS, et al. Inflammatory bowel disease and the risk of fracture. Gastroenterology 2003;125:1591-7.

4 Marshall D, Johnell $O$, Wedel $H$. Meta-analysis of how well measures of bone mineral density predict occurrence of osteoporotic fractures. BMJ 1996;312:1254-9.

5 Taylor BC, Schreiner PJ, Stone KL, et al. Long-term prediction of incident hip fracture risk in elderly white women: study of osteoporotic fractures. J Am Geriatr Soc 2004;52:1479-86.

6 Jahnsen J, Falch JA, Aadland E, et al. Bone mineral density is reduced in patients with Crohn's disease but not in patients with ulcerative colitis: a population based study. Gut 1997;40:313-19.

7 Siffiledeen JS, Fedorak RN, Siminoski K, et al. Bones and Crohn's: risk factors associated with low bone mineral density in patients with Crohn's disease. Inflamm Bowel Dis 2004; 10:220-8.

8 Schulte C, Dignass AU, Mann K, et al. Reduced bone mineral density and unbalanced bone metabolism in patients with inflammatory bowel disease. Inflamm Bowel Dis 1998;4:268-75.

9 Robinson RJ, al-Azzawi F, lqbal SJ, et al. Osteoporosis and determinants of bone density in patients with Crohn's disease. Dig Dis Sci 1998;43:2500-6.

10 Pollak RD, Karmeli F, Eliakim R, et al. Femoral neck osteopenia in patients with inflammatory bowel disease. Am J Gastroenterol 1998;93:1483-90.

11 Andreassen H, Hylander E, Rix M. Gender, age, and body weight are the major predictive factors for bone mineral density in Crohn's disease: a casecontrol cross-sectional study of 113 patients. Am J Gastroenterol 1999;94:824-8.

12 Silvennoinen JA, Lehtola JK, Niemela SE. Smoking is a risk factor for osteoporosis in women with inflammatory bowel disease. Scand J Gastroenterol 1996;31:367-71. 
13 Ralston SH. Genetic determinants of susceptibility to osteoporosis. Curr Opin Pharmacol 2003;3:286-90.

14 Spector TD, Keen RW, Arden NK, et al. Influence of vitamin D receptor genotype on bone mineral density in postmenopausal women: a twin study in Britain. BMJ 1995:310:1357-60.

15 Hustmyer FG, Peacock M, Hui S, et al. Bone mineral density in relation to polymorphism at the vitamin D receptor. J Clin Invest 1994;94:2130-4.

16 Cooper GS, Umbach DM. Are vitamin D receptor polymorphisms associated with bone mineral density? J Bone Miner Res 1996;1 1:1841-9.

17 Dawson-Hughes B, Harris SS, Finneran S. Calcium absorption on high and low calcium intakes in relation to vitamin D receptor genotype. J Clin Endocrinol Metab 1995;80:3657-61.

18 Simmons JD, Mullighan C, Welsh KI, et al. Vitamin D receptor gene polymorphism: association with Crohn's disease susceptibility. Gut 2000;47:211-14

19 Manolagas SC, Jilka RL. Bone marrow, cytokines and bone remodelling. N Engl J Med 1995;332:305-11

20 Murray RE, McGuigan F, Grant SF, et al. Polymorphisms of the interleukin-6 gene are associated with bone mineral density. Bone 1997;21:89-92.

21 Schulte CM, Dignass AU, Goebell H, et al. Genetic factors determine extent of bone loss in inflammatory bowel disease. Gastroenterol 2000;1 19:909-20.

22 Willing MC, Pruchno CJ, Atkinson M, et al. Osteogenesis imperfecta type I is commonly due to a COL1A1 null allele of type I collagen. Am J Hum Genet 1992:51:508-15.

23 Uitterlinden AG, Burger $\mathrm{H}$, Huang Q, et al. Relation of alleles of the collagen type 1(alpha) 1 gene to bone density and the risk of osteoporotic fractures in postmenopausal women. N Engl J Med 1998;338:1016-21.

24 Grant SF, Reid DM, Blake G, et al. Reduced bone density and osteoporosis associated with a polymorphic Spl binding site in the collagen type I alpha gene. Nat Genet 1996; 14:203-5

25 Mann V, Hobson E, Li B, et al. A COL1A1 Spl binding site polymorphism predisposes to osteoporotic fracture by affecting bone density and quality. J Clin Invest 2001;107:899-907.

26 Hugot JP, Chamaillard M, Zouali H, et al. Association of NOD2 leucine-rich repeat variants with susceptibility to Crohn's disease. Nature 2001;411:599-603

27 Cuthbert AP, Fisher SA, Mirza MM, et al. The contribution of NOD2 gene mutations to the risk and site of disease in inflammatory bowel disease. Gastroenterology 2002; 122:867-74

28 Bartram SA, Peaston RT, Rawlings DJ, et al. A randomized controlled trial of calcium with vitamin $D$, alone or in combination with intravenous pamidronate, for the treatment of low bone mineral density associated with Crohn's disease. Aliment Pharmacol Ther 2003;18:1121-7.

29 Kanis JA. Assessment of fracture risk and its application to screening for postmenopausal osteoporosis: synopsis of a WHO report. WHO Study Group. Osteoporos Int 1994;4:368-81.
30 Ferrari SL, Garnero P, Emond S, et al. A functional polymorphic variant in the interleukin- 6 gene promoter associated with low bone resorption in postmenopausal women. Arthritis Rheum 2001;44:196-201.

31 Lorentzon M, Lorentzon R, Nordstrom P. Interleukin-6 gene polymorphism is related to bone mineral density during and after puberty in healthy white males: a cross-sectional and longitudinal study. J Bone Miner Res 2000;15:1944-9

32 Schulte CMS, Goebell H, Roher HD, et al. Genetic determinants of IL-6 expression levels do not influence bone loss in inflammatory bowel disease. Dig Dis Sci 2001;46:2521-8.

33 Manolagas SC. Role of cytokines in bone resorption. Bone 1995; 17:63S-7.

34 Manolagas SC. The role of IL-6 type cytokines and their receptors in bone. Ann N Y Acad Sci 1998;840:194-204.

35 Scheidt-Nave C, Bismar H, Leidig-Bruckner G, et al. Serum interleukin 6 is a major predictor of bone loss in women specific to the first decade past menopause. J Clin Endocrinol Metab 2001;86:2032-42.

36 Fishman D, Faulds $G$, Jeffery $R$, et al. The effect of novel polymorphisms in the interleukin-6 (IL-6) gene on IL-6 transcription and plasma IL-6 levels, and an association with systemic-onset juvenile chronic arthritis. J Clin Invest 1998; 102:1369-76.

37 Eastell R, Reid DM, Compston J, et al. A UK Consensus Group on management of glucocorticoid-induced osteoporosis: an update. J Intern Med 1998;244:271-92

38 Mann V, Ralston SH. Meta-analysis of COL1A1 Spl polymorphism in relation to bone mineral density and osteoporotic fracture. Bone 2003:32:711-17.

39 Martin K, Radlmayr M, Borchers R, et al. Candidate genes colocalized to linkage regions in inflammatory bowel disease. Digestion 2002;66:121-6.

40 Card T, West J, Hubbard R, et al. Hip fractures in patients with inflammatory bowel disease and their relationship to corticosteroid use: a population based cohort study. Gut 2004;53:251-5.

41 Vestergaard P, Mosekilde L. Fracture risk in patients with celiac disesae, Crohn's disease and ulcerative colitis: a nationwide follow-up study of 16,416 patients in Denmark. Am J Epidemiol 2002;156:1-10.

42 Bernstein CN, Blanchard JF, Leslie W, et al. The incidence of fractures among patients with IBD: a population-based study. Ann Intern Med 2000;133:795-9.

43 Loftus EV, Crowson CS, Sandborn WJ, et al. Long-term fracture risk in patients with Crohn's disease: a population-based study in Olmstead County, Minnesota. Gastroenterology 2002;123:468-75

44 Adadchi JD, Bensen WG, Brown J, et al. Intermittent etidronate therapy to prevent corticosteriod induced osteoporosis. N Engl J Med 1997:337:382-7.

45 Sambrook PN, Kotowicz M, Nash P, et al. Prevention and treatment of glucocorticoid-induced osteoporosis: a comparison of calcitriol, vitamin D plus calcium, and alendronate plus calcium. J Bone Miner Res 2003;18:919-24.

\section{EDITOR'S QUIZ: GI SNAPSHOT}

\section{Answer}

From question on page 1535

Abdominal $x$ ray showed dilated loops of the small bowel with a metal oesophageal stent in the left iliac fossa. The suspicion of stent ileus was confirmed by computed tomography (fig 2) which showed dilated loops of small bowel proximal to the stent. A minilaparotomy was performed which found the small bowel to be dilated down to the site of impaction of the oesophageal stent in the terminal ileum. Unfortunately, the patient developed pneumonia after operation and died three days later.

Stent migration is a recognised complication of oesophageal stenting, occurring in up to $35 \%$ of treated patients. It occurs more frequently if the stent is placed across the gastrooesophageal junction. Provided the patient is asymptomatic, a "wait and see" approach is often reasonable for those with a migrated stent. Indeed, it is not unusual for the migrated stent to be passed spontaneously in stool. Endoscopic retrieval of the stent may be possible if it lies within the stomach. Open surgical removal of the migrated stent is reserved for cases of bowel obstruction or perforation.

doi: $10.1136 /$ gut.2005.069161

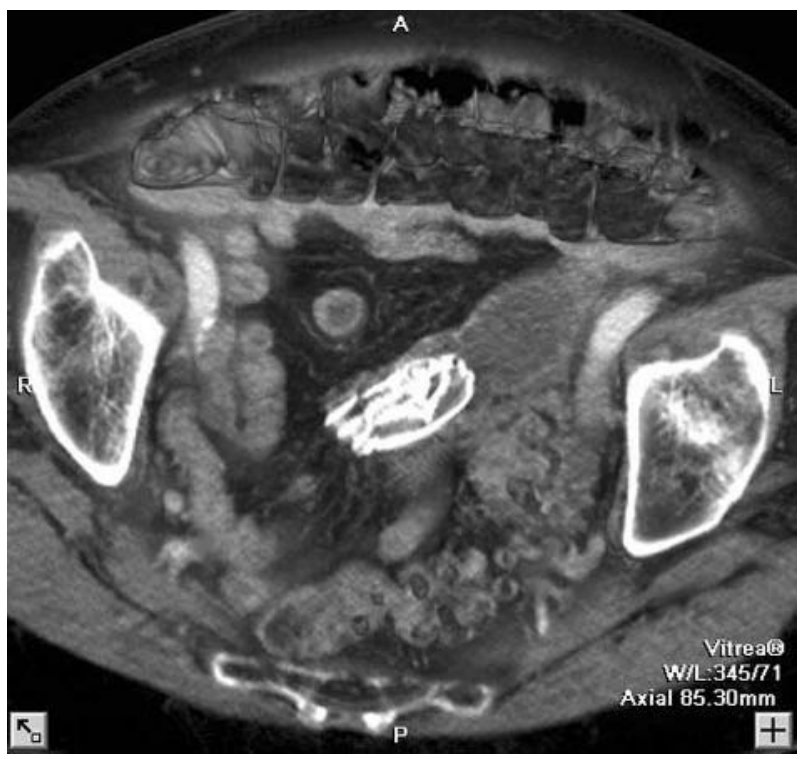

Figure 2 Computed tomography scan of the patient. The small bowel is dilated down to the level of the impacted stent. The large bowel is normal. 